Journal of Humanities and Social Sciences Studies (JHSSS)

ISSN: 2663-7197

DOI: 10.32996/jhsss

Journal Homepage: www.al-kindipublisher.com/index.php/jhsss

\title{
Perception of Climatic Change and Farmers' Decision to Adapt in the Sudano-sahelian Zone in Cameroon
}

\author{
William Nemkenang Koguia ${ }^{1} \square$ Fidoline Ngo Nonga ${ }^{2}$, Ali Madi ${ }^{3}$, Antoine Leblois ${ }^{4}$ and Mabah Tene \\ Gwladys Laure ${ }^{5}$ \\ ${ }^{7}$ Faculty of Economics and Management, University of Yaoundé II-Sao, Cameroon. \\ ${ }^{2}$ Faculty of Economics and Management, University of Douala, Douala, Cameroon \\ ${ }^{3}$ Faculty of Economics and Management, University of Maroua, Maroua, Cameroon \\ ${ }^{4}$ INRA, Institut National de la Recherche Agronomique. Center for Environmental Economics - Montpellier \\ 5IRAD, Institute for Agricultural Research and Development, Yaoundé, Cameroon
}

$\square$ Corresponding Author: William Nemkenang Koguia, E-mail: nemkes2001william@gmail.com

\section{ARTICLE INFORMATION ABSTRACT}

Received: 08 September 2021

Accepted: 05 October 2021

Published: 25 October 2021

DOI: $10.32996 /$ jhsss.2021.3.10.3

\section{KEYWORDS}

Climate change; Index perception; decision to adapt, Heckman probit method (selection effect control)
The objective of this study is to analyze the influence of farmers' perceptions on the decision to adapt to climate change in the Sudano-Sahelian zone of Cameroon. Based on a random draw from 721 farm households. This research shows that $98.6 \%$ of respondents in the study area reported having observed significant changes in climatic conditions. In addition, $89 \%$ of farmers have adopted at least one strategy to deal with these changes. Heckman's model shows that pessimistic perception about future climate precedes farmers' decision to adapt to climate change. The results also show that gender, membership of a farmer organization, religious beliefs, age, and sources of information are the main determinants of producers' perception and decision to adapt to climate change.

\section{Introduction}

Africa is subject to a highly unpredictable climate. This situation weakens the agricultural systems which no longer respond to actual climate pressure (Yegbemey et al., 2014). Kurukulasuriya et al. (2006) have already brought light on the vulnerability of agriculture to climate change in Africa, exacerbated by the high dependence of economies on agriculture and the relatively low adaptation capacity (Lack of infrastructures, Low incomes) of the population.

Facing the acceleration and intensification of socio-economic and environmental changes, the adaptation of the African agricultural system is even more crucial (Moran, 2000). Climatic change is inevitable in the short run and the principal political option to reduce the negative impact of climatic changes is an adaptation (Adger et al., 2003; Kurukulasuriya et Mendelsohn, 2008; Reilly, 2011). According to Mendelsohn et al. (1994), farmers will be seriously affected if they do not react to new climatic conditions by adopting adaption strategies

In Cameroon, agriculture generates, in average years, $22 \%$ of Gross Domestic Product (GDP) and contributes more than 55\% in trade dealings, provides more than $50 \%$ of raw materials to industries, and is the principal source of revenue and employment of the active population (World Bank 2003, 2007; DSDS, 2005). Agriculture which is still mainly rainfed and carried out by smallholders, therefore, remains largely dependent on climatic variations.

The research work carried out in 2015 in the context of national adaptation to climatic change (MINEPDED, 2015), shows that in Cameroon, the average rainfall from the period of $1981-2000$ is 20 to $40 \%$ lower than that of the period 1961-1980. We can observe a regression in precipitation since 1960 of about $-2.2 \%$ by decade (giving about $3 \mathrm{~mm}$ at least each month), and shortening the duration of the rainy season in the countries. A global increase in temperature has been observed those recent years. Rapid rates of increase are recorded in March, April, and May with $0.19^{\circ}$ by decade. In the sudano-sahelian zones, the rates of a rapid rise in

Copyright: (c) 2021 the Author(s). This article is an open access article distributed under the terms and conditions of the Creative Commons Attribution (CC-BY) 4.0 license (https://creativecommons.org/licenses/by/4.0/). Published by Al-Kindi Centre for Research and Development, London, United Kingdom. 
temperature are recorded in December, January, February, September, October, November, with rates being $0.2^{-0.4^{\circ}}$ by decade (PNUD, 2008).

Research works (Molua, 2002, 2006, 2008), show that the agriculture in Cameroon shall be highly affected by climatic change. These results are in line with those of Ouedraogo (2012) et Jeder et al. (2013) in Burkina Faso, Da Silva (2009) in Canada, Mendelsohn et al. (1994) in the US.

This situation obliges farmers to develop adaptation strategies in order to preserve their means of subsistence. The majority of research on the determinants of adaptation to climatic change lay emphasis only on the demographic and socio-economic characteristics of farmers. However, according to Maddison (2007), Gbetibouo (2009), and Yegbemey et al., (2014), adaptation is a result of both perceptions of the evolution of climate and demographic and socio-economic characteristics. It is important that research should also take into consideration the perception of producers of the said climatic change. This article has as objective to describe simultaneously the perception and adaptation of farmers to climate change in the sudano-sahelian zone of Cameroon. This article is organized as follows: Section I is the introduction; section II examines the literature review on perception and the adaptation of farmers to climatic changes; section III presents the methodology and empirical model; section IV presents the results and Section $\mathrm{V}$ presents the conclusions and the implications in terms of public policy.

\section{Literature Review}

The notion of risk perception emerged in the late 60 s during the anti-nuclear protest movements in the United States between the " objectives » risks of experts and the " perceived or subjective » risks of laymen (Finucane et al., 2000; Slovic, 1992; Slovic et al., 1979). Experts used to address risk through potential consequences and the probability of occurrence (Marris, 2001). For the laymen, qualitative dimensions varied their perception, their vision composed of believes, value scales, etc. (Rowe et Wright, 2001). Then the dichotomy between the risk perceptions of experts and laymen fades (Starr, (1969) cited by (Heitz, 2009)) with the evolution of research on perception, notably through the integration of methods and concepts from the social sciences. This made it possible to integrate risk managers the integration of risk managers (an important link in the communication and information between the "experts" and "laymen") and all the actors (individuals, communities) directly related to any risk into research investigations. Perceptions were no longer seen as distortions but as representations of a reality influenced by many factors inherent to individuals (Kouabenan et al., 2007; Marris, 2001), regardless of their field of action. We then find the notions of belief (Douglas, 1967; Douglas et Wildavsky, 1983; Kunreuther et al., 1988) and responsibility used in the cultural or psychometric theories of classification of perceptions. In many studies, perception links individual judgment of risk and action (O'Riordan (1986), in others, perception goes beyond the individual, it is a social and cultural construction that integrates values, symbols, history and ideology (Sjöberg et al., 2004).

According to Van Den Ban and Hawkins (1996), perception is a process by which an individual receives information and stimuli from his environment and transforms them into conscious psychological acts. Two types of perception are distinguished in the human perception model: psychic perception related to the psychological situation of the individual and the sensory perception that is related to the senses (Yegbemey et al., 2014). Psychological perception is a function of functional factors such as experiences, notions of values, expectations, needs, opinions and socio-cultural norms. (Van Den Ban et al., 1994). Sensory perception depends on structural factors which our five senses (sight, taste, smell, hear and touch).

This model of analysis is applied as well to climate change, given that farmers do not adapt directly to the change in question but according to the manner in which they conceived and perceived. Climatic change is just a stimuli where the visible response is adaptation. Adaptation is a response to observable change responding to forces or perturbations such as climatic change (Smithers et Smit, 1997), an increase in the prices of fertilizers etc. In this perspective, the ultimate goal of adaptation to climatic change will be to moderate the negative impact of this change, to confront its consequences and eventually benefit from its new opportunities (Adger et al., 2003).

With the perception of climatic change being an observed stimulus, the adaptation decision of farmers will be a reasoned process. This leads us to the theory of reasoned action developed by Fishbein et Ajzen (1975). According to this theory, the strategy adopted by the producer will be determined by his behavioural intention to adopt.

With these theoretical considerations, the main hypothesis according to which the adaptation of the producers given the stimuli such as climatic change is only coherent regarding their conception and perception

\section{Methodology}

\subsection{Study area and data}

The data was obtained from an interview using a sample size of 721 agricultural exploitations in the North and Far North regions of Cameroon. This survey was sponsored by the Institute of Agricultural Research for Development (IRAD) of Garoua, under "C2D agro-system's" project, and carried out from July to September 2014. It includes a questionnaire composed of open and closed questions which allows us to categorize farms according to socio-economic characteristics (age, level of education, the main 
activity of the family head, family size, surface area, etc.); production systems, (agricultural inputs, equipment, and labor force used); socio-institutional environment of the exploitation (access to loans, access to vulgarization, etc.); the perception of the exploitation leaders of climatic change and finally the different adaptation strategies to climatic risk.

We are now moving to a agro-ecological zone realized by Dugué et al. (1994). This zoning took into consideration the physical characteristics (climate and soil), demographical (density and population movement), the potentials and constraints, level of agricultural equipment, cultures in the regions, type of soils, and economic criteria (presence of markets, accessibility). This zoning culminated in seven (07) sub zones. In function of security dispositions and action zones of the project, four out of the seven zones were retained. In each of the chosen zone, a sample of 200 farms was obtained by random draw.

Figure I. Agro-ecological zoning of the Northern and Far North Regions in Cameroon

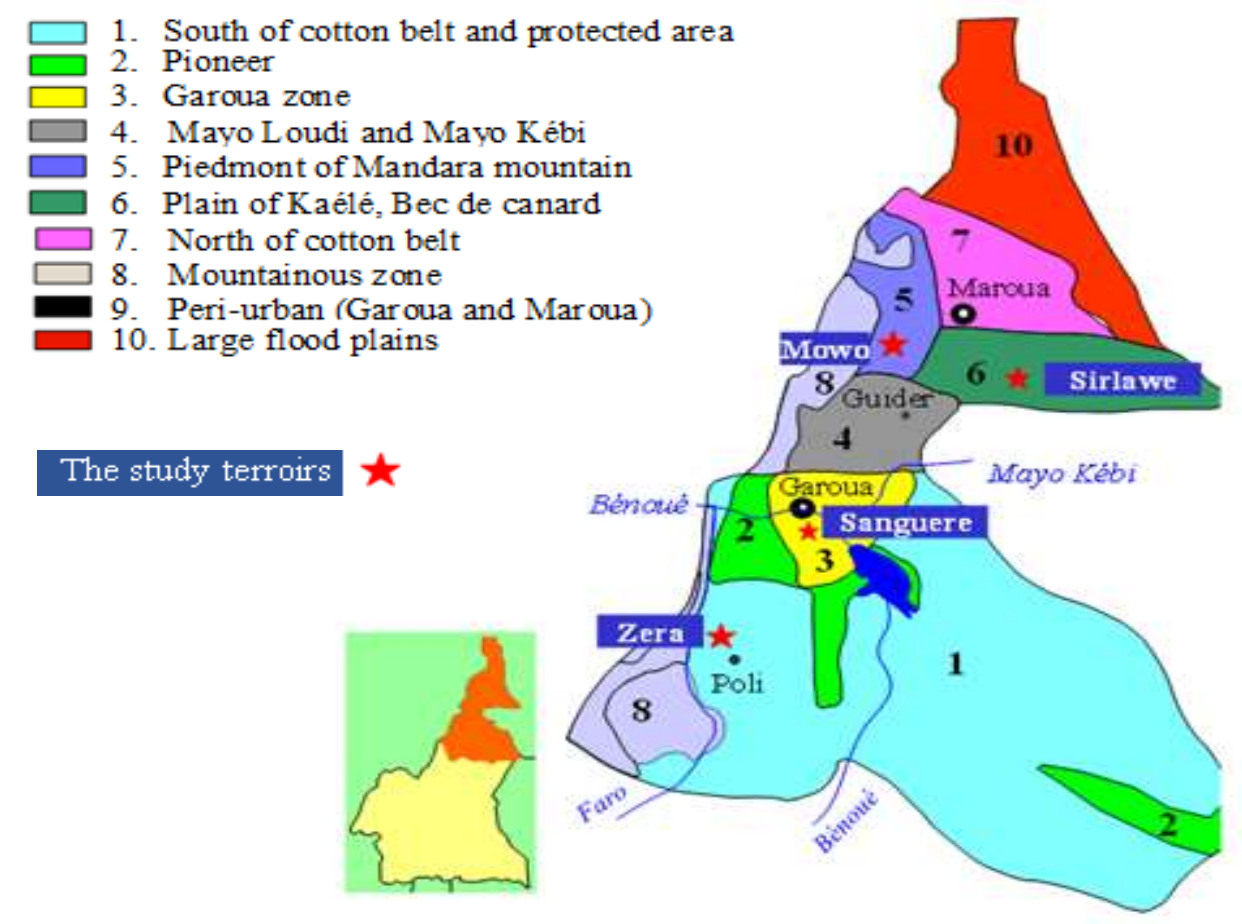

Source: Adapted from, Dugué et al.(1994 )

The reject rates for questionnaires are $7,5 \%$ and $10,5 \% 17 \%$ and $4,5 \%$ respectively in the MOWO, SIRLAWE, ZERA and SANGUERE territories. It involves incomplete questionnaires, doubtful answers given by interviewees and finally the farmers not having as the main agricultural activity. The second one constituted only $5.2 \%$ of the sample and was thus rejected.

Table I : Results of the interview

\begin{tabular}{|l|l|l|l|l|l|}
\hline \multicolumn{2}{|l|}{} & MOWO & SIRLAWE & ZERA & SENGUERE \\
\hline Questionnaires administered & 200 & 200 & 200 & 200 \\
\hline $\begin{array}{l}\text { Questionnaires } \\
\text { retained }\end{array}$ & 721 & 185 & 179 & 166 & 191 \\
\cline { 2 - 6 } & $90,13 \%$ & $92,5 \%$ & $89,5 \%$ & $83 \%$ & $95,5 \%$ \\
\hline
\end{tabular}

Source : author's calculations using interviews ran in 2014

\subsection{Treatment of perception data: Calculation of the perception index of climatic change in the sudano-sahelian zone}

The calculation of the risk perception indices has been under many research studies (Glatron et Beck, 2008; Kunreuther et al., 1988; Lindell et Barnes, 1986; Slovic et Peters, 2006). We have been inspired by the psychometric paradigm which defines important factors to be integrated in estimation of indices. This method was also chosen because it provides a good translation of the representations that are qualitative data into quantitative data. The choice of our variables was based on the works of Kahneman et Tversky (1979). According to the psychometric paradigm, the evaluation of the perception was made thanks to notation scales 
fixed around nine dimensions permitting quantitatively translate the representation of a risk by the sampled individuals. Therefore, we have a voluntary character of risk-taking, the immediate effect of risk, the knowledge of risk, its controllable or reducible character, its recent character, its chronic or permanent character, the threat it represents, and its potentially catastrophic character (Sjöberg et al., 2004; Slovic, 1992).

The data collected does not permit us to consider the set of factors presented in the literature. In addition, the nature of risk requires us to ignore certain factors such as: the voluntary or suffered nature of the risk and the recent nature of the risk. Indeed, the climatic phenomenon is general and automatically applies to all people living in the same agro-ecological zone. Moreover, climate change is continuous and therefore cannot be analyzed as one-off phenomenon. However, on the basis of this literature, we identified two major groups of factors which seem necessary in the realization of our objectives. So we have:

- The knowledge of risk: evaluated amongst others by the level of information on the evolution of the climatic phenomenon.

The question «according to you, what are the major changes that in the last 10 years in the climate of the zone?», permits the surveyed to directly express their knowledge of the climatic parameters of the zone. This is an open question and the answers are debatable and requiring re-coding.

We do not wish to highly intervene in the adaptation of the discussion so as to minimize any bias with respect to re-coding.

We chose to use a semantic grouping because individuals do not always use the same terms to express the same idea. This question enables the surveyed to reveal his optimistic or pessimistic vision of climate. For example, the recognition of an increase in temperature indicates a state of mind where surveyed sees the future climate. Besides, many other questions permitted to measure the knowledge on the variability of climate through the beginning and end of the rainy season as well as a Spatiotemporal variability of precipitations.

- The threat it represents and its chronic character

It measured among others by the apprehension that the population has on the consequences of the climatic phenomenon. The answers of the farmers with respect to the consequences of climatic change materializes the supportable or not-supportable character of climatic risks. The threat of climatic change necessitates the examination of the questions related to the consequences of climatic change on the social activities. Also, the "climate pessimists" hold that climatic change negatively influences activities. However, all responses which indicate a negative influence on the farmer's activities indicate the pessimism of the investigation given the climatic change.

Based on the study of Kahneman et Tversky (1979), we will define the necessary variables in the construction of our index. The methodology of construction of the composite indicator of perception of climatic change is based on the inertia approach with the help of multidimensional analyses. The choice of this technique is due to the fact that it permits to eliminate as much as possible arbitrary in the calculation of a composite indicator. The technique of factorial analysis which is more adapted in our case, is that of multiple correspondence analysis since all the variables are qualitative.

In order to generate the indexes of perception of climatic changes, we will proceed to the realization of ACM on the set of available and pertinent variables which characterize climatic changes as well as their consequences on the zone of study. To ameliorate our indicator, we shall proceed to the reduction of the number of variables resulting from the first ACM following a certain number of criteria. The principal criteria is that of ordinal consistence on the first factorial axe (COPA). This property consists of a partial indicator having its ordinal structure respected by the coordinates of its modalities on the first factorial axle. The realization of a second ACM with the remaining variables permitted to ameliorate the explicative power of the first factorial axle for the COPA principle was respected. Finally, we constructed from the results of the second ACM the composite indicator of perception of climatic changes with respect to the inertia approach.

\subsection{Processing of adaptation data}

After the questions related to perception, a series of two questions were used to define the variable « adaptation to climatic change ». The first question was: "Have you taken some measures to reduce the negative effects of climatic change on your activities? ". Afterwards, the strategies developed in the framework of adaptation to climatic change were reviewed through the question: "If yes, did you adopt one of the following measures?"

\subsection{Choice of model}

The Logit and Probit models are commonly used to analyze the choice of determinants or the decision of the producers to carry out adjustments or modifications (Gbetibouo, 2009; Hassan et Nhemachena, 2008; Maddison, 2007). According to the nature of the dependent variable, the multinomial models are equally used. These models are presented in the general form as follows: 
(1) $A_{i}=f Z_{I}$ Where $A_{i}$ and $Z_{I}$ Represent the decision of adaptation of farmer $\mathrm{i}$ and a set of demographic and socio-economic characteristics of the same farmer i respectively. While considering the hypothesis of the relationship perception-adaptation, the simplest manner of integrating the perception of producer $(P)$ in the previous model is expressed as:

(2) $\quad A_{i}=f Z_{I}, P_{I}$

However, still on the theoretical framework, perception appears as an endogenous variable (depends on a certain number of individual characteristics). The estimation of the second equation presents endogenous bias. In these conditions, the specification of two distinct models, that is to say an adaptation model (equation 3) and perception model (equation 4) appear as an alternative that will reduce the estimation bias:

(3) $A_{i}=f Z_{I}$

(4) $P_{i}=f Y_{I}$

Where $Y_{I}$ represents a set of demographic and socio-economic characteristics of the same farmer $\mathrm{i}$; who could be identical or different from $Z_{I}$.

This new formulation which reduces the endogeneity device related to perception does not take into account the hypothesis according to which adaptation of farmers face with stimuli such as climatic change. According to Maddison (2007), perception is a prerequisite to adaptation. In other words, you need to perceive before adapting. The problem of endogeneity is no longer posed rather the problem of selection. Also as proposed Maddison (2007), (Gbetibouo, 2009) et (Yegbemey et al., 2014) a selection model like the Probit of Heckman model permits to better exploit the adaptation decision of farmers in relation with their perception. By so doing, the general model becomes:

(5) $A_{i}=f Z_{I}$ If and only if $\mathrm{s} P_{i}=f Y_{I}>0$

The defined form is based on two sub-models: output or adaptation model where the dependent variable is adaptation (A) and the selection model where the dependent variable is perception $(P)$. Considering $j$, the demographic and socio-economic characteristics related to farmer capable of determining its adaptation decision (noted characteristics $Z_{I j}$ ) on one hand and $\mathrm{j}^{\prime}$ demographic and socio-economic characteristics related to the same farmer I and is susceptible of determining its perception (noted characteristics $Y_{I j}$ ) on the other hand, the resulting economic model is:

(6) $a_{i}=\alpha 0+\sum_{j} \alpha_{j} Z_{i j}+u_{i}$ sietseulementsip $_{i}=\beta 0+\sum_{j^{\prime}} \beta_{j^{\prime}} y_{i j^{\prime}}+v>0$

In this model, $a_{i}$ the adaptation decision ( $1=$ adapt $; 0=$ do not adapt) of farmer $\mathrm{i}$ and $P_{i}$ its perception defined as a silent dichotomy variable ( 1 = perceive $; 0=$ do not perceive) $; \alpha$ and $\beta$ are variables to be estimated; finally, $u$ and $v$ are the errors terms. Equation (6) becomes:

(7) $\quad A=\alpha Z+U P=\beta Y+V$

where $\mathrm{Z}$ is a j-vector of the demographic and socio-economic characteristics which could influence the adaptation decision, $\mathrm{Y}$ is a $\mathrm{j}$-vector of the demographic and socio-economic characteristics which could determine perception, $\mathrm{U}$ and $\mathrm{V}$ are the error terms following the normal distribution independently from $X$ and $Y$, and $A$ and $P$ are linked by the selectivity link $A$ if $P>0$. Also, the dependent variable $A$ is defined as:

(8) $A$ is observed if $P>0 A$ is lacking data if $P \leq 0$

From these observations and specifications, the farmers' characteristics such as the possession of a secondary activity, the number of agricultural assets per household, experience in agriculture, ownership right over the exploited land, access to loans, membership in an organization and contact were introduced in the adaptation model, and experience in agriculture, sex, educational level and membership in a farmers organization were introduced in the perception model. In our empirical model, the dependent variable of the selection model is a binary variable and indicates if the farmer has a pessimistic or optimistic perception of climatic parameters in the zone. In order to render the scores in the dichotomy form, we will start from non-normalized scores. The dependent variable of the result equation is also binary and indicates if the farmer decides to adapt or not after perception.

Table II: Presentation of the variables of the model 
JHSSS 3(10): 22-33

\begin{tabular}{|c|c|c|c|c|}
\hline Variable & Types & Modalites & Frequency & Expected signs \\
\hline \multicolumn{5}{|c|}{ Adaptation model (output modèle) } \\
\hline \multirow{2}{*}{ Adaptation choice } & \multirow{2}{*}{ Dichotomous } & $0=\mathrm{No} ;$ & 11.10 & \\
\hline & & $1=$ Yes & 88.90 & \\
\hline \multirow{2}{*}{ Secondary Activity } & \multirow{2}{*}{ Dichotomous } & No $=0$; & 38.83 & \multirow{2}{*}{+} \\
\hline & & Yes $=1$ & 61.17 & \\
\hline \multirow{3}{*}{ Age } & & 1 : less than 30 years old; & 16.37 & \multirow{3}{*}{ \pm} \\
\hline & & 2: Age between 30 and 50; & 54.09 & \\
\hline & & $3:$ Age over 50 & 29.54 & \\
\hline \multirow{2}{*}{ Wealth level } & & $0=$ Poor (less than 500,000$)$ & 61.03 & \multirow{2}{*}{+} \\
\hline & & $1=$ Rich (more than 500000) & 38.97 & \\
\hline \multirow{2}{*}{ Information source } & \multirow{2}{*}{ Dichotomous } & $0=$ informal; & 27.05 & \multirow{2}{*}{+} \\
\hline & & $1=$ formal & 72.95 & \\
\hline \multirow{2}{*}{$\begin{array}{l}\text { Member of } \quad \text { farmer } \\
\text { organisation (POs) }\end{array}$} & \multirow{2}{*}{ Dichotomous } & No $=0$; & 79.06 & \multirow{2}{*}{+} \\
\hline & & Yes $=1$ & 20.94 & \\
\hline \multirow{3}{*}{ Area } & & $1=$ semi-arid; & 67.27 & \multirow{3}{*}{ \pm} \\
\hline & & $2=$ subhumid; & 23.86 & \\
\hline & & $3=$ peri-urban & 8.88 & \\
\hline \multirow{2}{*}{ Education } & \multirow{2}{*}{ Dichotomous } & No $=0$; & 61.03 & \multirow{2}{*}{+} \\
\hline & & Yes $=1$ (having attained at least secondary) & 38.97 & \\
\hline \multicolumn{5}{|c|}{ Modèle de perception (modèle de sélection) } \\
\hline \multirow{2}{*}{ Perception } & \multirow{2}{*}{ Dichotomous } & $0=$ pessimistic ; & 61,58 & \\
\hline & & 1 = optimistic & 38.42 & \\
\hline \multirow{2}{*}{ Religious belief } & \multirow{2}{*}{ Dichotomous } & $0=\mathrm{No} ;$ & 24.55 & \multirow{2}{*}{-} \\
\hline & & $1=$ Yes & 75.45 & \\
\hline \multirow{2}{*}{ Sex } & & $0=$ Women ; & 10.12 & \\
\hline & Dichotomous & $1=$ Man & 89.88 & \pm \\
\hline lnctrustion & Dichotomous & No $=0$ & 61.03 & + \\
\hline mistruction & Dichotomous & Yes = 1 (having reached at least secondary) & 38.97 & + \\
\hline & & 1 : less than 30 years old; & & \\
\hline Age & & 2: Age between 30 and 50 & & + \\
\hline & & $3:$ Age over 50 & & \\
\hline Member of farmer & Dichotomous & No $=0$; & 79.06 & + \\
\hline organization (POs) & Dichotominas & Yes $=1$ & 20.94 & + \\
\hline llnformation sourc & Dichotomous & $0=$ informal $;$ & 27.05 & 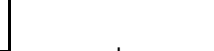 \\
\hline |ntormation source & Dicnotomous & $1=$ formal & 72.95 & + \\
\hline Serendary artivity & Dichotomous & No $=0$ & & + \\
\hline pecondary Activity & Dicnotomous & Yes $=1$ & & + \\
\hline
\end{tabular}

Source : Data from our survey, 2014. 
- The knowledge of risk: evaluated amongst others by the level of information on the evolution of the climatic phenomenon.

This permits us to realized that climatic change is not only observed by the researchers because for more than two decades now the population has noticed a certain « deregulation » in the normal order of things as it was in the past. About $98.6 \%$ of the research carried out in the zone confirm to have noticed a considerable modification in the climatic conditions of the zone. These changes are seen locally through the indicators conceived by the farmers so as to establish a reference framework as presented in the following table.

Table III: Perception of modifications of certain parameters.

\begin{tabular}{lll}
\hline & Yes (\%) & No (\%) \\
\hline Temperature increase & 54 & 46 \\
Decrease in the number of rain days & 69,80 & 31,20 \\
Increasing the length of the dry season & 72 & 38 \\
drying up of wells & 8 & 92 \\
Floods & 20 & 80 \\
\hline
\end{tabular}

Source : Data from our survey, 2014.

The $69.8 \%$ of the agricultural areas we interviewed had perceived changes through a reduction in the number of days rainfalls throughout the rainy season.

For some who haven perceived climate changes, these modifications are at the level of the raining season by: I) a late onset of the rainy season (71.71\%) and an early end (55.89\%). 54.09\% of farmers think that the rain is poorly distributed during the rainy season leading to dryness. Equally, $46.19 \%$ of the investigations declares a bad spatial distribution of rain in the land.

Table IV : perception of beginnings and end of rainy season

Can you appreciate the Spatio-temporal distributions of precipitation?

\begin{tabular}{|c|c|c|}
\hline & Better distributed (\%) & Poorly distributed (\%) \\
\hline Spatial distribution of rainfall & 53,81 & 46,19 \\
\hline Temporal distribution of précipitations & 45,91 & 54,09 \\
\hline \multicolumn{3}{|c|}{ Can you specify the trend of the beginning and the end of the rain season? } \\
\hline Earlier (\%) & No change (\%) & Later $(\%)$ \\
\hline Start of the rain season & 5,27 & 71,71 \\
\hline End of rain season & 5,55 & 38,56 \\
\hline
\end{tabular}

Source : Data from our survey, 2014.

Generally, the analysis of these results permits us to see that in the study zone, there exist a deregulation in the starts and end of seasons having as consequences the reduction of the raining season and the extension of the dry season.

- The threat it represents and its chronic character.

Given the heterogeneity of the physical environment, the incidences differ from one topography to the other and the vulnerability of different units of the landscape depends on the degree of their exposure to climate. This heterogeneity of the physical environment as well-conditioned the distribution of the resulting effects and affected persons as we present in the following table.

Table V : Perception des conséquences des changements climatiques 


\section{In your opinion, what is the impact of climate change on the following events?}

\begin{tabular}{lccc}
\hline & Decreases (\%) & No change (\%) & Increases (\%) \\
\hline Drought & 19 & 14 & 66 \\
\hline Drought severity & 19,83 & 12,07 & 68,07 \\
\hline Flood & 43,41 & 8,88 & 47,71 \\
\hline Epizootic & 45,63 & 14,29 & 40,08 \\
\hline Epidemics & 36,48 & 19,56 & 43,97 \\
\hline Crop failure & 34,40 & 19,42 & 46,19 \\
\hline Animal water deficiency & 30,24 & 21,91 & 47,85 \\
\hline Insufficiency of family water & 32,18 & 20,39 & 47,43 \\
\hline Food shortage & 31,35 & 18,31 & 50,35 \\
\hline Conflicts & 22,19 & 22,88 & 54,92 \\
\hline Insecurity & 27,32 & 17,89 & 54,79 \\
\hline insect growth & 36,75 & 14,15 & 49,10 \\
the increase of rodents & 40,08 & 14,15 & 45,77 \\
\hline
\end{tabular}

Source: Data from our survey, 2014.

The analyses of scattered points were obtained in ACM. This axe explains $73 \%$ of the total scattered variables while the second axe has weak explanatory power (6.6\%). This distinction of the first axe puts a particular phenomenon which climatic change. The analysis of ACM is mainly circumscribed to this axe describing the phenomenon of climatic change. In observing the first factorial plan, we observed that the variables translating a critical and undoubtedly state of the climate are found on the left and that indicating a normal or advantageous climate is found on the right. The higher the perception index of climatic changes, the more the individual is skeptical of changes and negative climatic effects and consequently an optimistic vision of climate. While a weak level of perception index means the individual has an understanding of negative changes with respect to climatic parameters as well as the negative effects of these changes in the zone. The individual in question, however, has a pessimistic conception of climate. The choice of the analysis in terms of the pessimistic or optimistic individual with respect to the risk of climatic changes is guided by the fact that the evaluation of risks is influenced by a certain number of beliefs on risks. These beliefs can be qualified as positive in the sense where it reflects the tendency of the individual to manifest optimism given their vulnerability to risks. On the other hand, these beliefs can be qualified as pessimistic when it entails a tendency of the individual to manifest fatalism with respect to their predisposition to succumb to risks.

In the study zone, these perception scores are found between -1, 21, and 2, 64 .

In accordance with the different orientations of the variables on the factorial axes we posed the postulate according to which an individual has a pessimistic perception when his perception score is less than zero and found between -1, 21, and 0; contrarily, an individual will have an optimistic perception if his perception score is greater than zero and found between 0 and 2, 64 .

\subsection{Adaptation to climatic changes}

In spite of a higher degree of intensity and/or the appearance of the new climatic constraints, the farmers have the attitude to composing with a certain climatic risk level using the adjustment means they have. $88.9 \%$ of farmers adopted at least a strategy to face the climatic mutations in the zone.

Table VI: strategies of the actors

\begin{tabular}{|l|l|l|l|}
\hline Adaptation strategies & Types & Modalités & Frequency (\%) \\
\hline \multirow{2}{*}{ Irrigation } & dichotomous & $1=$ Yes & 63 \\
\cline { 3 - 4 } & & $0=$ No & 37 \\
\hline \multirow{2}{*}{ Diversification of activities } & dichotomous & $1=$ Yes & 87 \\
\cline { 3 - 4 } & & $0=$ No & 13 \\
\hline \multirow{2}{*}{ Increased use of fertilizers } & dichotomous & $1=$ Yes & 77 \\
\cline { 2 - 4 } Extension area & & $0=$ No & 23 \\
\hline cropping systems under vegetation cover & dichotomous & $1=$ Yes & 59 \\
\cline { 3 - 4 } (UVC) & & $0=$ No & 41 \\
\hline
\end{tabular}




\begin{tabular}{|l|l|l|l|}
\hline \multirow{2}{*}{ Short cycle seed } & dichotomous & $1=$ Yes & 69 \\
\cline { 3 - 4 } & & $0=$ No & 31 \\
\hline \multirow{2}{*}{ shift of the sowing period } & dichotomous & $1=$ Yes & 39 \\
\cline { 3 - 4 } & & $0=$ No & 61 \\
\hline \multirow{2}{*}{ Fallow } & dichotomous & $1=$ Yes & 42 \\
\cline { 3 - 4 } & & $0=$ No & 58 \\
\hline
\end{tabular}

Source: Data from our survey, 2014

\subsection{Perception and adaptation determinants of climatic change}

The estimation results show that the model is globally significant at the limit of $1 \%$, car Prob $>$ chi $2<0,01$.

Rho is negative and significant at $5 \%$ which shows that an optimistic perception of climate in the region negatively influences the adaptation decision of the farmers. According to the perception paradigm (Adesina et Zinnah, 1993), this study shows the existence of a significant association between the perception of extreme climatic events and the adaptation decision of the smallscale farmers in the sudano-sahelian zone. The latter are consequently rational and integrate the evolution of their environment in the decision-making. In conformity with the theory, a producer in a risky environment will first proceed by evaluating the risk. Then he will choose protective measures Villa et Bélanger (2012) or he will choose to be protected against this risk if he thinks he can confront it. These results corroborate with those of de Gbetibouo (2009) in the Limpopo basin in South Africa and those of Kansiime et al. (2014) in Uganda which also show that adaptation to climatic change is an appropriate response to the different perceptions which the producers have on the evolution of their environment.

Table VII: Result of the selection model of Heckman

\begin{tabular}{|c|c|c|c|c|c|c|c|c|}
\hline \multirow{2}{*}{ Variables } & \multicolumn{4}{|c|}{ Output modèl (adaptation) } & \multicolumn{4}{|c|}{ Selection Modèle (perception) } \\
\hline & Coefficient & Erreur type & $\mathrm{T}$ & $P>t$ & Coefficient & Erreur type & $T$ & $P>t$ \\
\hline Religious belief & - & - & - & - & $-0,377^{\star \star \star}$ & 0,119 & $-3,17$ & 0,002 \\
\hline Sex & - & - & - & - & $0,521^{\text {***}}$ & 0,171 & 3,04 & 0,002 \\
\hline $\begin{array}{l}\text { Age between } 30 \\
\text { and } 50\end{array}$ & 0,211 & 0,250 & 0,85 & 0.398 & $-0,129$ & 0,144 & $-0,90$ & 0,368 \\
\hline Age over 50 & 0,425 & 0,284 & 1,50 & 0.134 & $-0,560^{\star \star \star}$ & 0,166 & $-3,36$ & 0,001 \\
\hline Education & $-0,208$ & 0,211 & $-0,98$ & 0.326 & 0,034 & 0,122 & 0,28 & 0,779 \\
\hline Wealth level & $-0,347^{\star}$ & 0,215 & $-1,61$ & 0.107 & - & - & - & - \\
\hline Semi-arid zone & $-0,174$ & 0,313 & $-0,56$ & 0.578 & - & - & - & - \\
\hline Subhumid zone & $1,392^{* * *}$ & 0,385 & 3,61 & 0.000 & - & - & - & - \\
\hline Information source & $-0,309$ & 0,230 & $-1,34$ & 0.180 & $0,258^{* \star}$ & 0,122 & 2,10 & 0,036 \\
\hline $\begin{array}{l}\text { Membership of } \\
\text { POs }\end{array}$ & $1,014 * * *$ & 0,391 & 2,59 & 0.010 & $-0,449 * \star *$ & 0,139 & $-3,23$ & 0,001 \\
\hline Secondary Activity & $0,679^{\star \star}$ & 0,215 & 3,16 & 0.002 & $-0,747^{\star \star *}$ & 0,111 & $-6,72$ & 0,000 \\
\hline Total area & $-0,003$ & 0,082 & $-0,03$ & 0.975 & $0,115^{\text {*** }}$ & 0,028 & 4,11 & 0,000 \\
\hline Constant & $1,071^{\text {*** }}$ & 0,410 & 2,61 & 0.009 & $-0,217$ & 0,265 & $-0,82$ & 0,413 \\
\hline Arthrho & $-1,5007^{* *}$ & 0,592 & $-2,53$ & & & & & \\
\hline Rho & $-0,905^{* *}$ & 0,107 & & & & & & \\
\hline Model Summary & \multicolumn{8}{|c|}{$\begin{array}{l}\text { Log likelihood }=-479,3408 ; \text { observations Number }=720 ; \text { Censored obs }=444 ; \\
\text { Uncensored obs }=276 ; \text { Wald chi } 2(10)=34,11 ; \text { Prob }>\text { chi } 2=0,0002\end{array}$} \\
\hline \multicolumn{9}{|c|}{$\begin{array}{l}\text { LR test of indep. eqns. }(\text { rho }=0): \text { chi2 }(1)=5.95 \text { Prob }>\text { chi2 }=0.0147 \\
* * *: \text { significant value } 1 \%(P \leq 0,01) ;{ }^{* *}: \text { significant value } 5 \%(0,01<P \leq 0,05) ;{ }^{*}: \text { significant value } 10 \% \\
(0,05<P \leq 0,10) \text {. }\end{array}$} \\
\hline
\end{tabular}

Source: Data from our survey, 2014

\section{- Member of farmer organization}

Membership of an organization is positively and significantly correlated with optimistic perception of climate (at statistic threshold of $1 \%$; probability $<0,01$ ) and adaptation (at statistic threshold of $1 \%$; probability $<0,01$ ) to climatic change. Village groups, especially farmer's associations benefit from the training offered by partners. Across these different structures, the producers are 
sensitized to the actual variability of climate as well as on the present and future consequences on agricultural production and on the immediate environment of man. To these sources of apprenticeship is added the relations existing between the producers and which serve as canals of sharing of experiences which can initiate the common adaptation initiative. Membership to an organization can then facilitate access to information and technical practices where positive correlations are observed. This result corroborates with that of Yegbemey et al. (2014) au Benin.

\section{- Carrying out a secondary activity}

Carrying out a secondary activity is also positively and significantly correlated with adaptation decision to climatic change at the threshold of $5 \%(0,01<$ probability $<0,05)$. A secondary activity constitutes another source of revenue for the producers. The revenue from the secondary activity can as well be used for investment such as manpower, fertilizers, and pesticide, new varieties, etc. The expected effect, in this case, is similar to that of access to loans. Besides, the diversification of activities is also an adaptation strategy to climatic change (Gnanglè et al., 2012; Maddison, 2007; Yegbemey et al., 2013) which permits minimizing the risk in case of bad harvest and hence loss of revenue. In this sense, the producers who already have a secondary activity have a high probability of adapting to climatic change.

- Level of wealth

In spite of its low rate, the level of wealth is negatively correlated with the producer's decision to adapt to climatic change at the statistic threshold of $10 \%(0,05<$ probability $<0,10)$. This result which seems paradoxical to expectations can be justified by the fact that poor farmers are most vulnerable to shocks that affect their revenue than rich farmers. Also, faced with chaos like floods, some farmers adopt autonomous strategies (Smit et al., 2001), while striving to stabilize their revenue than its maximization.

- $\operatorname{Sex}$

Though positive, the correlation between sex and optimistic perception of climatic changes is statistically significant (probability $\square 0,01$ ). This sexy-specificity of perception of climatic changes does not corroborate with the results of other studies (Gandure et al., 2013; Sanchez et al., 2012). However, this result finds its justification in the theory which considers the effect as heuristic judgment (Finucane et al., 2000; Loewenstein et al., 2001; Slovic et al., 2004; Slovic et al., 2005). According to this theory, the evaluation of risk shall be affected by the emotional state of the subject perceiving as well as by the emotional tone (positive or negative valence) associated with the event. This result corroborates with many other research works in the literature. According to Slovic (1999), many research works have shown that men try to judge risks in a weak and least problematic manner than women.

\section{- Zone effect}

The farmers in the sub-humid zone are more likely to adapt than those in per urban; the coefficient of this zone is positive and Significantly linked to adaption choices, with a $1 \%$ chance of error.

In spite of the degree of intensity and/or the appearance of new climatic constraints, the adaptation decision depends on the significant manner of perception that farmers have on such changes. The farmers do have the attitude to be content with a certain level of climatic risk in the function of the way they use the adjustment means at their disposal. However, the latter generally face many strategies which they combine at their convenience to attend to their objectives.

\section{Conclusion}

The agricultural producers in the sudano-sahelian zone in Cameroon perceive climatic changes and develop diverse strategies to adapt. These changes are seen through rainfall and thermal disturbances, as well as by an increase in extreme events. The diversification of sources of activities, adjustment of cultural practices, and agricultural calendar is the principal adaptation strategies developed as a response to perceived climatic changes. Sex, membership in an organization, religious beliefs, age, and information sources are the main determinants of perception and adaptation decision of producers to climatic change. Particular attention was to be given to these different determinants in the context of the implementation of policies to promote agriculture in the context of climatic changes. Also, regular sessions to raise awareness, training, exchange, and sharing of knowledge related to future climatic conditions and the adaptation to climatic changes could constitute potential intervention tools, oriented towards producer's organizations through popularization services.

Acknowledgments: All authors are grateful to the Institute of Agricultural Research for Development (IRAD) of Garoua for providing data through the North" C2D agro-system's" project. The findings and opinions expressed in this paper are exclusively those of the authors. The authors are also solely responsible for the content and any errors.

\section{References}

[1] Adesina, A. A. et Zinnah, M. M. (1993). Technology characteristics, farmers' perceptions and adoption decisions: A Tobit model application in Sierra Leone. Agricultural Economics, 9(4), 297-311.

[2] Adger, W. N., Huq, S., Brown, K., Conway, D. et Hulme, M. (2003). Adaptation to climate change in the developing world. Progress in development studies, 3(3), 179-195. 
[3] Da Silva, L. (2009). L'impact économique des changements climatiques sur l'agriculture canadienne. (Mémoire M. S.C), HEC MONTRÉAL, Canada.

[4] Douglas, M. (1967). Purity And Danger: Routledge.

[5] Douglas, M. et Wildavsky, A. (1983). Risk and culture: An essay on the selection of technological and environmental dangers. California: Univ of California Press.

[6] Dugué, P., Koulandi, J. et Moussa, C. (1994). Diversité et zonage des situations agricoles et pastorales de la région cotonnière du NordCameroun IRA-IRZV, Projet Garoua 2. Garoua (Cameroun).

[7] Finucane, M. L., Alhakami, A., Slovic, P. et Johnson, S. M. (2000). The affect heuristic in judgments of risks and benefits. Journal of behavioral decision making, 13(1), 1-17.

[8] Fishbein, M. et Ajzen, I. (1975). Belief, attitude, intention, and behavior: an introduction to theory and research. Reading (MA, USA: AddisonWesley Pub (Sd).

[9] Gandure, S., Walker, S. et Botha, J. (2013). Farmers' perceptions of adaptation to climate change and water stress in a South African rural community. Environmental Development, 5, 39-53.

[10] Gbetibouo, G. A. (2009). Understanding farmers' perceptions and adaptations to climate change and variability: The case of the Limpopo Basin, South Africa (Vol. 849): Intl Food Policy Res Inst.

[11] Glatron, S. et Beck, E. (2008). Evaluation of socio-spatial vulnerability of city-dwellers and analysis of risk perception: industrial and seismic risks in Mulhouse. Natural Hazards and Earth System Sciences, 8(5), 1029-1040.

[12] Gnanglè, P., Yabi, J. A., Yegbemey, N. R., Kakaï, R. et Sopkon, N. (2012). Rentabilité économique des systèmes de production des parcs à Karité dans le contexte de l'adaptation au changement climatique du Nord-Bénin. African Crop Science Journal, 20(2), 589-602.

[13] Griliches, Z. (1957). Hybrid corn: An exploration in the economics of technological change. Econometrica, Journal of the Econometric Society, 501-522.

[14] Hassan, R. et Nhemachena, C. (2008). Determinants of African farmers' strategies for adapting to climate change: Multinomial choice analysis. African Journal of Agricultural and Resource Economics, 2(1), 83-104.

[15] Heitz, C. (2009). La perception du risque de coulées boueuses: analyse sociogéographique et apports à l'économie comportementale. Thèse de Doctorat Université de Montpellier.

[16] Jeder, H., Khalifa, A. B. et Sghaier, M. (2013). Impact des changements climatiques sur l'agriculture dans la plaine de Jeffara sud-est tunisien. Journal of Agriculture and Environment for International Development (JAEID), 107(2), 229-242.

[17] Kahneman, D. et Tversky, A. (1979). Prospect theory: An analysis of decision under risk. Econometrica: Journal of the econometric society, 263-291.

[18] Kansiime, K., Shisanya, A. et Wambugu, K. (2014). Effectiveness of technological options for minimizing production risks under variable climatic conditions in eastern Uganda. African Crop Science Journal, 22, 859-874.

[19] Kouabenan, D. R., Cadet, B., Hermand, D. et Sastre, M. T. M. (2007). Percevoir et évaluer les risques: les apports de la psychologie en matière de traitement des informations. In D. R. Kouabenan, B. Cadet, D. Hermand \& M. T. M. Sastre (Eds.), Pychologie du risque (pp. 29-42): De Boeck Supérieur.

[20] Kunreuther, H., Desvousges, W. et Slovic, P. (1988). Risk perceptions and attitudes toward a high-level nuclear waste repository in Nevada. Environment, 30(8), 16-33.

[21] Kurukulasuriya, P. et Mendelsohn, R. (2008). A Ricardian analysis of the impact of climate change on African cropland. African Journal of Agricultural and Resource Economics, 2(1).

[22] Kurukulasuriya, P., Mendelsohn, R., Hassan, R., Benhin, J., Deressa, T. et Diop, M. (2006). Will African agriculture survive climate change? World Bank Economic Review, 20, 367-388.

[23] Lindell, M. K. et Barnes, V. E. (1986). Protective response to a technological emergency: risk perception and behavioral intention. Nuclear safety, 27(4), 457-467.

[24] Loewenstein, G. F., Weber, E. U., Hsee, C. K. et Welch, N. (2001). Risk as feelings. Psychological bulletin, 127(2), 267.

[25] Maddison, D. (2007). The perception of and adaptation to climate change in Africa (Vol. 4308): World Bank Publications.

[26] Marris, C. (2001). La perception des OGM par le public: remise en cause de quelques idées reçues. Économie rurale, 266(1), 58-79.

[27] Mendelsohn, R., Nordhaus, W. D. et Shaw, D. (1994). The impact of global warming on agriculture: a Ricardian analysis. The American economic review, 753-771.

[28] MINEPDED. (2015). Plan National d'Adaptation aux Changements climatiques du Cameroun: Ministre de l'Environnement et de la Protection de la Nature et du Développement Durable.

[29] Molua, E. L. (2002). Climate variability, vulnerability, and effectiveness of farm-level adaptation options: the challenges and implications for food security in Southwestern Cameroon. Environment and Development Economics, 7(03), 529-545.

[30] Molua, E. L. (2006). Climatic trends in Cameroon: implications for agricultural management. Climate Research, 30(3), $255-262$.

[31] Molua, E. L. (2008). Turning up the heat on African agriculture: The impact of climate change on Cameroon's agriculture. African Journal of Agricultural and Resource Economics, 2(1), 45-64.

[32] Moore, G. C. et Benbasat, I. (1996). Integrating diffusion of innovations and theory of reasoned action models to predict utilization of information technology by end-users. In Diffusion and adoption of information technology (Ed.), (pp. 132-146): Springer.

[33] Moran, E. F. (2000). Human Adaptability. Boulder: Westview Press.

[34] O'Riordan, T. (1986). IO Coping with Environmental Hazards. Geography, Resources, and Environment, 2, 272.

[35] Ouedraogo, M. (2012). Impact des changements climatiques sur les revenus agricoles au Burkina Faso. Journal of Agriculture and Environment for International Development (JAEID), 106(1), 3-21.

[36] PNUD. (2008). Climate Change Country Profiles. Cameroun, http://www.heliointernational.org/uploads/VARCameroun.Fr.

[37] Reilly, J. M. (2011). Overview: Climate Change Adaptation in the Agricultural Sector. In J. D. Ford \& L. Berrang-Ford (Eds.), Climate Change Adaptation in Developed Nations: From Theory to Practice (pp. 347-357). Dordrecht: Springer Netherlands.

[38] Rogers, E. M. (1962). Diffusion of Innovations: The Free Press New York. 
[39] Rowe, G. et Wright, G. (2001). Differences in expert and lay judgments of risk: myth or reality? Risk analysis, 21(2), 341-356.

[40] Sanchez, A. C., Fandohan, B., Assogbadjo, A. E. et Sinsin, B. (2012). A countrywide multi-ethnic assessment of local communities' perception of climate change in Benin (West Africa). Climate and Development, 4(2), 114-128.

[41] Sjöberg, L., Moen, B.-E. et Rundmo, T. (2004). Explaining risk perception: An evaluation of the psychometric paradigm risk perception research (Vol. 84): Rotunde, Norwegian University of Science and Technology Departement of Psychology.

[42] Slovic, P. (1992). Perception of risk. Reflections on the psychometric paradigmes. In S. Krimsky \& D. Goldin (Eds.), Social theories of risk, (pp. 117-152): SPraeger.

[43] Slovic, P. (1999). Trust, emotion, sex, politics, and science: Surveying the risk-assessment battlefield. Risk analysis, 19(4), 689-701.

[44] Slovic, P., Finucane, M. L., Peters, E. et MacGregor, D. G. (2004). Risk as analysis and risk as feelings: Some thoughts about effect, reason, risk, and rationality. Risk analysis, 24(2), 311-322.

[45] Slovic, P., Fischhoff, B. et Lichtenstein, S. (1979). Rating the risks. Environment, 21(3), 14-20 ; 36-39.

[46] Slovic, P. et Peters, E. (2006). Risk perception and affect. Current directions in psychological science, 15(6), 322-325.

[47] Slovic, P., Peters, E., Finucane, M. L. et MacGregor, D. G. (2005). Affect, risk, and decision-making. Health psychology, $24(4 \mathrm{~S})$, S35.

[48] Smit, B., Pilifosova, O., Burton, I., Challenger, B., Huq, S., Klein, R. J. T., .. W Wandel, J. (2001). Adaptation to Climate Change in the Context of Sustainable Development and Equity. In J. J. McCarthy, O. F. Canziani, N. A. Leary, D. J. Dokken \& K. S. White (Eds.), Impacts, Adaptation, and Vulnerability: Contribution of Working Group II to the Third Assessment Report of the Intergovernmental Panel on Climate Change, Cambridge: Cambridge University Press, pp. 877-912.

[49] Smithers, J. et Smit, B. (1997). Human adaptation to climatic variability and change. Global Environmental Change (7), $129-146$.

[50] Van Den Ban, A. W. et Hawkins, H. S. (1996). Agricultural extension: Blackwell Science.

[51] Van Den Ban, A. W., Hawkins, H. S. et Brauwer, S. J. (1994). La vulgarisation rural en Afrique. Paris Wageningen: Éditions Karthala.

[52] Villa, J. et Bélanger, D. (2012). Perception du risque d'inondation dans un contexte de changements climatiques: recension systématique des articles scientifiques sur sa mesure (1990-2011) Montréal: Institut national de santé publique du Québec.

[53] Yegbemey, R. N., Yabi, J. A., Aïhounton, G. B. et Paraïso, A. (2014). Modélisation simultanée de la perception et de l'adaptation au changement climatique: cas des producteurs de maïs du Nord Bénin (Afrique de l'Ouest). Cahiers agricultures, 23(3), 177-187 (171).

[54] Yegbemey, R. N., Yabi, J. A., Tovignan, S. D., Gantoli, G. et Kokoye, S. E. H. (2013). Farmers' decisions to adapt to climate change under various property rights: A case study of maize farming in northern Benin (West Africa). Land Use Policy, 34, 168-175. 